\title{
Слово редактора
}

Цей номер «Українського релігієзнавства» (УР) є першим в 2019 році, яким ми відкриваємо нову сторінку в історії нашого фахового видання. Здійснена повна оцифровка всіх номерів УР від 1996 року, які виставлені на інтернетсторінці Національної бібліотеки України імені В.I. Вернадського, розташували журнал на новій платформі OpenJournalSestem, увійшли до декількох наукометричних баз, що відповідають за глобальну індексацію наукових публікацій (Google Scholar, Copernicus). Нами оновлено склад редакції, куди введені всесвітньо знані релігієзнавці. Змінена наша редакційна політика, про що чітко написали на своїй сторінці. Тепер вона стала більш прозорою і відкритою: всі статті до УР подаватимуться через інтернет і проходитимуть подвійне сліпе рецензування. Таким чином ми наближаємося до світових стандартів написання і публікування наукових статей.

Як показав досвід, це справа не проста, але завдяки зусиллям перш за все авторів, рецензентів, членів і співробітників редакції журналу нам вдалося опанувати нові вимоги, що робить перспективу входження до міжнародних наукометричних баз даних більш реальною. Тепер про наші наукові досягнення світова спільнота дізнаватиметься скоріше, а наша присутність в світовому науковому просторі буде помітніша і ефективніша.

Ми хочемо наш журнал зробити не архівом статей, які пишуться під дисертації або отримання наукових звань, а оживити наукову дискусію, привернути увагу до релігіє- 
знавчих проблем, які виникали в минулому, але надзвичайно актуалізувалися зараз. Теми, пов'язані із релігією, мали б цікавити не тільки фахівців, але й широке коло читачів.

В залежності від надісланих матеріалів ми формуватимемо основні рубрики, які були присутні і в попередні роки: історія та філософія релігії, соціологія та етнологія релігії тощо. 3'являться нові рубрики, пов'язані із друком документів та архівних матеріалів, статистичних даних.

Саме тому цей номер відкриває інформаційно-аналітична стаття «Релігійна мережа України 2018», яка базується на аналізі цифрового матеріалу, наданого Департаментом у справах національностей і релігій Міністерства культури України про релігійну мережу країни. Щороку такі дані збираються по всіх областях, що надає можливість краще орієнтуватися в релігійному полі нашої держави, розуміти основні тенденції його змін.

В рубриці «Філософія релігї представлена стаття доктора філософських наук, зав. кафедрою філософії та релігієзнавства Східноєвропейського національного університету імені Лесі Українки, відомого дослідника релігійної повсякденності Юрія Борейка. Автор в своїй статті пропонує поновому подивитися на «Подію як протиставлення повсякденності віруючого».

Історичний блок увібрав дві статті молодих дослідниць: Олена Бороденко «Підготовка до обряду вінчання у XVIII - першій половині XIX ст. (на основі матеріалів дозвільної документації)» та Наталія Головата «Чудотворні ікони Богородиці та семіотика світового дерева».

Солідно представлений розділ, присвячений Icmopii релігієзнавства. Ми плануємо поступово описати інституалізацію релігієзнавства в Україні як узагальнюючими та аналітичними статтями, так і документальними матеріалами 
(інтерв'ю, архіви, спомини тощо). Перша спроба дати «Історію Української асоціації релігієзнавців (УАР): постання та інституалізація» ініційована доктором філософських наук, зав. відділом філософії та історії релігії ВР ІФ НАНУ Людмилою Филипович.

3'явилася нова рубрика «Наукова дискусія», яку відкриває доктор філософських наук Олег Шепетяк своєю статею «Релігієзнавче поняття "політеїзм" як результат мовленнєвого непорозуміння». Ця стаття стала результатом роздумів, які з'явилися у професора під час дослідження ним світового релігійного процесу в його трьохтомній «Історії релігій», яка має вийти друком у цьому році.

Давно мріяли зробити постійною рубрику Рецензіі, відгуки, рекомендації, чим сподіваємося оживити наукове релігієзнавче буття, заохотити до читання та критичного обговорення праць, які виходять в світ із під пера вітчизняних та закордонних вчених. I першою такою ластівкою є рецензія на монографію Титаренко В.В. «Від пророцтв в релігії до прогнозів у релігієзнавстві: історія, теорія, перспективи» кандидата наук Юлії Смець-Доброносової.

Запрошую до читання оновленого часопису «Українське релігієзнавство» і сподіваюсь спонукати вас стати і його авторами, і його рецензентами.

До зустрічі на сторінці https://uars.info/index.php/uars!

Натхненно,

Головний редактор часопису

«Українське релігієзнавство»

професор Анатолій КОЛОДНИЙ 